\title{
生体内での低出力超音波照射による生体活性純チタンの 骨結合機能の促進効果*
}

\author{
小林 正典 ${ }^{* 1}$, 北原 義大 ${ }^{* 2}$, 白石 将文 ${ }^{* 2}$, 木下 光雄 ${ }^{* 2}$
The Enhancement of Bone-Bonding Ability of the Bio-Active Pure Titanium by Low Intensive Supersonic wave in vivo \\ Masanori KOBAYASHI ${ }^{*}$, Yoshihiro KITAHARA, Masafumi SHIRAISHI and Mitsuo KINOSHITA \\ ${ }^{* 1}$ Daido Univ. Dept.of Integral Mechanical Engineering \\ Takiharu-cho 10-3, Minami-ku, Nagoya, 457-8530 Japan
}

We have already reported the in vitro effect of the ultrasound wave stimulation for the hydroxyapatite-like crystalline formation on bioactive pure titanium surface, which indicate the clinical advantage to accelerate the bone-binding to bioactive material. In this study, animal experiment was performed in order to investigate the effect of ultrasound waving in vivo. Bioactive pure titanium was processed by the chemical treatment and the heat treatment, implanted to the rabbits femur, and undertaken the irradiation of ultrasound waving for planned time-periods. The titanium specimens taken from sacrificed rabbit was assessed by using Scanning Electron Microscope (SEM), histological observation and mechanical testing. As a result, the bone-bonding condition of titanium sample of the ultrasound waving radiation group was significantly excellent as compared with the non-ultrasound pulse group. These findings supported the result of previous in vitro study and suggested that the ultrasound waving had clinical potential to improve the osteointegration, bone-bonding ability for bioactive titanium implant.

Key Words : Biomaterial, Biological Hard Tissue, Medical Engineering, Orthpaedic Biomechanics, Ultrasound

\section{1. 緒言}

以前より, チタン材料は優れた生体適合性を示寸ことから力学的な強度や耐久性が要求される整形外科や歯科 用のインプラント材料として使用されているが，近年，特殊な表面処理を施して生体骨と直接結合する骨伝導性 の能力を高めた生体活性チタンが開発されるようになってからは，その研究および臨床応用にはますます注目が 集まっている．しかしながら，生体活性チタンは，他の生体骨との結合機能を持つ材料，ハイドロキシアパタイ 卜等と比べると，まだ骨との直接結合には時間を要し，このためリハビリテーションや術後の ADL（日常活動性： Activity of Daily Life）など臨床の観点から，さらに早期に結合させるための方策が研究されている

小久保ら (2) によって, 生体活性チタンの骨伝導機能をもつ材料表面の骨との結合メカニズムには, 表面でのア パタイトの結晶析出過程とその後の骨組織のハイドロキシアパタイトとの結合過程が存在することが示され, 特 にアパタイトの析出おとび成長では, 物理化学的な要素が大きいことが示唆されている. そこで我々は, 結晶学 的な観点から, 難治骨折の骨形成促進に利用されている低周波超音波が有効ではないかと考え, 生体活性チタン と骨との結合促進への応用のために，擬似体液に漬けた生体活性化チタンに超音波を照射し，骨様のハイドロキ シアパタイト系化合物の析出の状況を観察する研究を行ってきた.

\footnotetext{
*原稿受付 2013 年 2 月 6 日

${ }^{* 1}$ 正員, 大同大学（广457-8530 愛知県名古屋市南区滝春町 10 番地 3 )

${ }^{*}$ 大阪医科大学医学部整形外科学教室

E-mail: mkoba@daido-it.ac.jp
} 
その結果，図 1,2 に示すように，走査型電子顕微鏡（SEM） 観察およびエネルギー分散型 X 線分光機(EDS) の分析から，超音波照射（USW）によって生体活性チタン表面でのアパタイトのようなリン酸カルシウム系の化 合物の析出が増加していることが観察された. さらに質量測定結果からも, USWによってその析出物が促進され ることが確認され (図 3)，これら in vitro での詳細は既に報告してきた ${ }^{(3,4)}$.

(a)

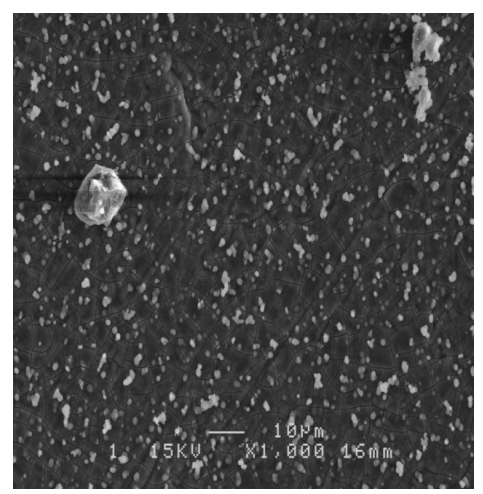

(b)

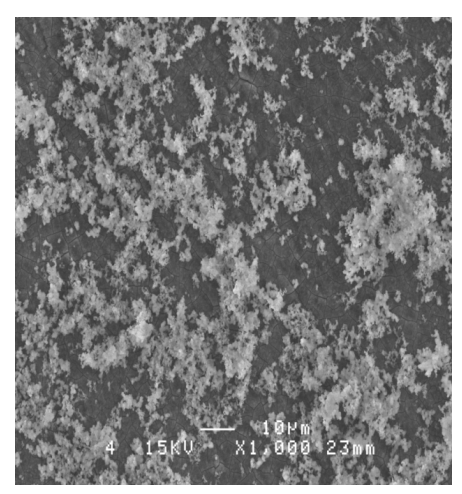

Fig.1.1 SEM micrographs of the surface of titanium after soaking in SBF for 1week
(a) without ultrasound wave
(b) using ultrasound wave
$(\times 1000)$

(a)

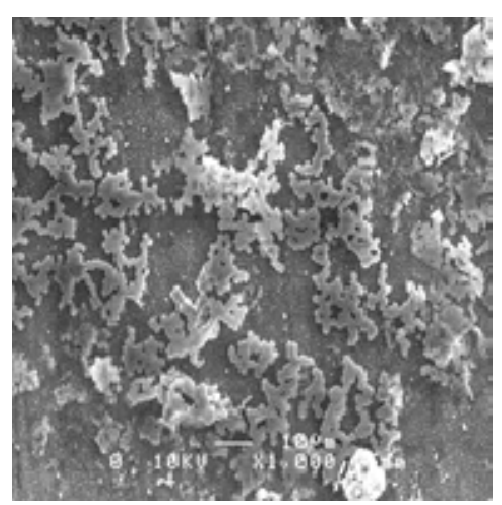

(b)

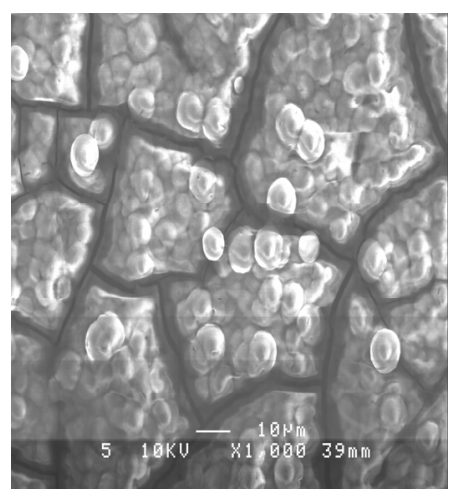

Fig.1.2 SEM micrographs of the surface of titanium after soaking in SBF for 2weeks
(a) without ultrasound wave
(b) using ultrasound wave
$(\times 1000)$

この超音波照射の $\mathrm{Ca} / \mathrm{P}$ 系化合物生成促進メカニズムについては，超音波照射群の照射 $1 \mathrm{~W}$ までに見られる結 晶の初期形態が，急激な結晶成長を示寸デンドライドに近い形状であったことから，結晶の核生成初期に超音波 の micro-waving による $\mathrm{P}$ や Ca イオンの濃度や熱の摇らぎが, チタン表面での不均一核生成 ${ }^{(5-7)}$ を促進したと考え られる．また，超音波によるキャビテーションなども， $\mathrm{Ca} / \mathrm{P}$ 系化合物の結晶析出過程でミクロな結晶破壊を引き 起こし，逆に結晶成長に適したエピタキシャルな面の創生に関与したと推測している. 
(a)

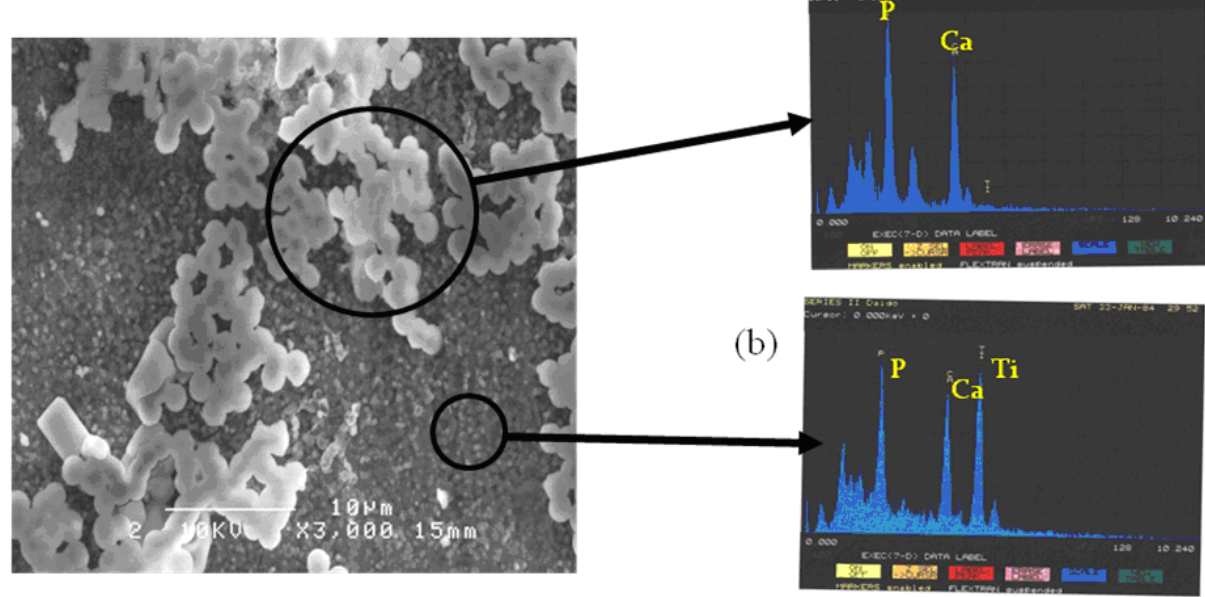

Fig.2 EDS analysis of Bioactive Ti surface soaked in SBF for 2 weeks

(a) The precipitation indicates the composition of rich phosphate $(\mathrm{P})$ and calcium $(\mathrm{Ca})$

(b) The based surface shows original titanium (Ti) with $\mathrm{P}$ and $\mathrm{Ca}$

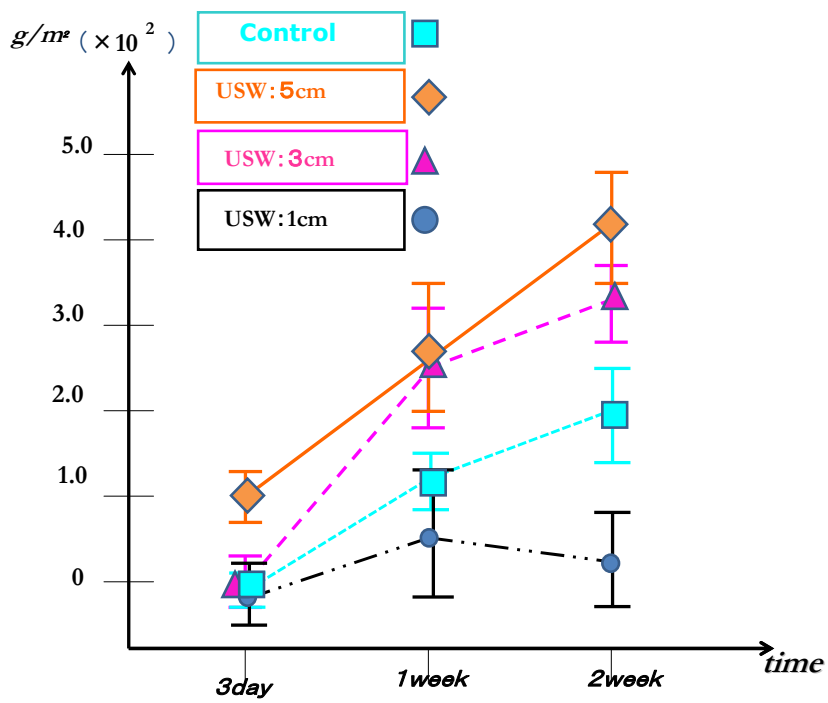

Fig.3 Time dependence of mass of $\mathrm{P} / \mathrm{Ca}$ precipitation formation on Ti surface

これらの結果から, 臨床的には, 超音波照射を行うことで生体活性チタンインプラントと生体骨との早期結合を 促進する可能性が期待された.

しかしながら，これらの実験結果は，いずれも，生体内を模した擬似体液中での生体活性化チタンへの超音波照 射の実験であり，臨床応用のための次のステップとしては，動物を用いた in vivo での実験が必要であった．そこ で今回我々はウサギを用いた動物実験を行い，実際の生体内での超音波照射の効果を見ることとした． 


\section{2. 実験方法}

\section{$2 \cdot 1$ 実験試料}

試験片として純チタン（大同特殊鋼 99.5\%）を使用した。まず試料表面をエメリー紙（\#120〜\#1000）で順次研 磨し, その後 $\mathrm{NaOH}[2 \mathrm{~mol} / 1]$ に 24 時間浸漬, 600 度の炉内で 1 時間熱処理をしたのち 24 時間炉冷し生体活性のた めの表面処理を施した。 これらの表面処理方法は，開発者の小久保らによって報告されている一般的なチタンの 生体活性化の方法 ${ }^{(8)}$ ) と同じである.

生体活性化したチタンは, $3 \times 3 \times 3[\mathrm{~mm}]$ の分析用試料と, $3 \times 3 \times 8[\mathrm{~mm}]$ の機械試験用試料の 2 種類の大きさに切り出 し，それぞれ動物実験に使用した。

\section{$2 \cdot 2$ 動物実験}

実験では，体重 2 3kg の白色家兔 8 羽（分析用； 4 羽，機械試験用；4 羽）を用い，上記方法で作製した生体 活性チタン試料を両側の大腿骨皮下および大腿骨骨内ヘインプラントした.

まずペントバルビタール静脈麻酔を施行し, 両側の大腿外側に皮切を加えて筋層と皮下組織の間にチタン試料 を設置，さらに大腿転子部にも皮切を加えて進入，大腿骨大転子部の骨を露呈させ，ドリルおよびヤスリにて骨 皮質に試料の大きさに合致するように骨孔を開けて，皮質骨から海綿骨部にかけてチタン試験片それぞれ一個を 埋入した.

この際, SEM や EDS での観察用試験片は, $3 \times 3 \times 3[\mathrm{~mm}]$ の立方体を用いて骨内に完全に埋没させ, 一方機械試 験（結合強度測定）用試験片では， $3 \times 3 \times 8[\mathrm{~mm}]$ の直方体試料を用いて，引き抜き試験でチタンを把持できるよ うに，5ミリほどの長さを大腿骨より出してインプラントした．全ての試験片の固定性が良好なことを確認した 後創内を洗浄, 皮下各層を縫合した。

術後ウサギは特に外固定等は行わず，ケージ内で自由に飼育し，術後翌日より一方の大腿骨のチタン試料埋入 部の直上大腿部（インプラント試料から約 $1.5 \mathrm{~cm}$ ) にジェルを塗布し超音波端子を当てて毎日 20 分間超音波照射 を行った. 超音波照射には, 実際の臨床でも使用されている超音波骨折治療器セーフス®（帝人ファーマ（株), 周波数 $1.5[\mathrm{MHz}]$ ）を用い，照射方法もマニュアル通りに行なった．反対側の大腿部は，超音波照射を行わず比 較対照（コントロール）群とした.

照射 2 週間後，ウサギを全身麻酔薬（ネンブタール）の過剩投与により安楽死させ，皮下と大腿骨転子部に入 れたチタンを取り出した，大腿骨骨内ヘインプラントした試験片は，周囲の骨ごと一塊として取り出し，それぞ れ以下の組織標本，走查電子顕微鏡観察試料および界面強度測定用試料の製作を行った．図 4 に屠殺したウサギ から取り出した大腿骨に埋め込んだチタンインプラントの外観を示す.

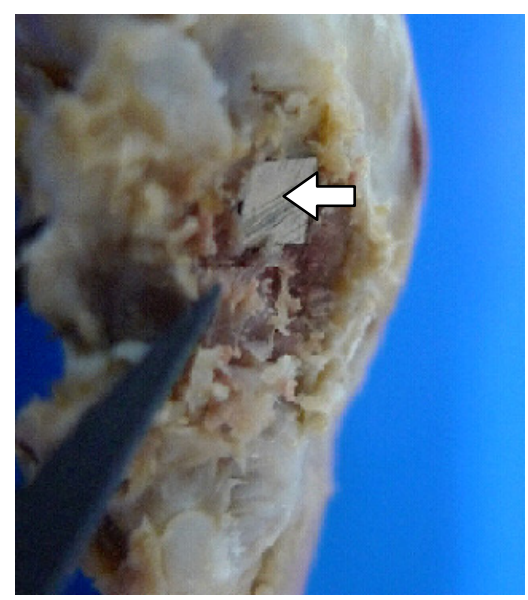

Fig.4 Macro appearance of rabbits femoral bone. Arrow $(\rightarrow)$ shows the Ti sample implant

以上の実験過程は，全て大阪医科大学動物実験倫理委員会の規定およびガイドラインに従って行われた. 


\section{$2 \cdot 3$ 分析}

得られた分析用チタン試料は，超音波照射群，コントロール群ともに皮下埋没，骨内インプラントそれぞれ 4 個で，以下の種類の分析に供して，超音波照射群とコントロール群（無照射対照群）とで比較・検討を行った.

\section{$2 \cdot 3 \cdot 1$ マイクロ観察および分析}

皮下に埋入したチタン試料は走査型電子顕微鏡(SEM ; JSM-6300F, (株)日本電子製 )にて表面状態を観察した. 骨に埋め込んだ試料は, ダイアモンド・ソーにてインプラント体の長軸に沿って切断し, そのまま蒸着処理をせ ずに，チタンと骨との界面をSEMにて観察した，さらに骨から引き抜いた後，そのチタン表面をSEMおよびエ ネルギー分散型 X 線分光機(EDS)，(JSM-6300F，(株)日本電子製 )を用いて観察した。

\section{$2 \cdot 3 \cdot 2$ 組織観察}

組織標本は，骨にインプラントした試料についてのみ作製した。骨と一塊として取り出した大腿骨転子部は， ホルマリン固定後，脱灰処理を施し，ポリメタクリル酸メチル（PMMA）樹脂に包埋固定して切片を作製,その後 定型的方法でヘマトキシリンーエオジン染色（H－E 染色）を行った. 超音波照射群とコントロール群（無照射 対照群）とでチタン周囲の骨組織の状態を観察し，比較・検討を行った.

\section{$2 \cdot 3 \cdot 3$ 機械試験}

骨と生体活性チタンとの結合強度を見るために，得られた試料，超音波照射群，コントロール群それぞれ 4 本 (n=4)について引き抜き試験を行った，試験機には，卓上型精密万能試験機オートグラフ AGS-J シリーズ（(株) 島津製作所）を使用し，大腿骨から軟部組織を剥離して $5 \mathrm{~mm}$ ほど露出させたチタン試料の片端を治具で把持し， 接着剤で固定して，ひずみ速度 $1.0 \mathrm{~mm} / \mathrm{min}$ で骨から引き抜いた.

この時の引き抜きに要した荷重を，チタン試料が骨に埋まっていた 5 面の総面積で除して，これを引き抜き強 度（MPa）とした。試験から得られた強度データは，分散分析（ANOVA）による統計処理を行い，超音波照射群 とコントロール群とで比較を行った。

\section{3. 実験結果}

\section{$3 \cdot 1 \quad S E M, E D S$ にる生体活性チタン試料表面のマイクロ観察}

\section{$3 \cdot 1 \cdot 1 \quad$ 皮下にインプラントしたチタン試料}

得られたデータのうち, 皮下に埋入させた生体活性チタン試料についての超音波照射群とコントロール群での チタン表面の SEM 画像を図 5 に示寸.

皮下にインプラントしたチタンの場合，超音波照射群，コントロール群いずれの場合も，疑似体液中に比べて 析出量が少なかったが，表面全体に薄いアパタイトと見られる層が形成されており，EDS の解析から in vitroの 実験結果と同様に，主組成はリンとカルシウムからなることが確認された。

超音波照射グループの試料表面では，この表層の上に一部に白い粒状の結晶析出が観察されたが，コントロー ル群では，チタン表面の層も薄くまだ粒部状析出物は確認できなかった。（図 $1.1 \& 1.2)$ 
(a)

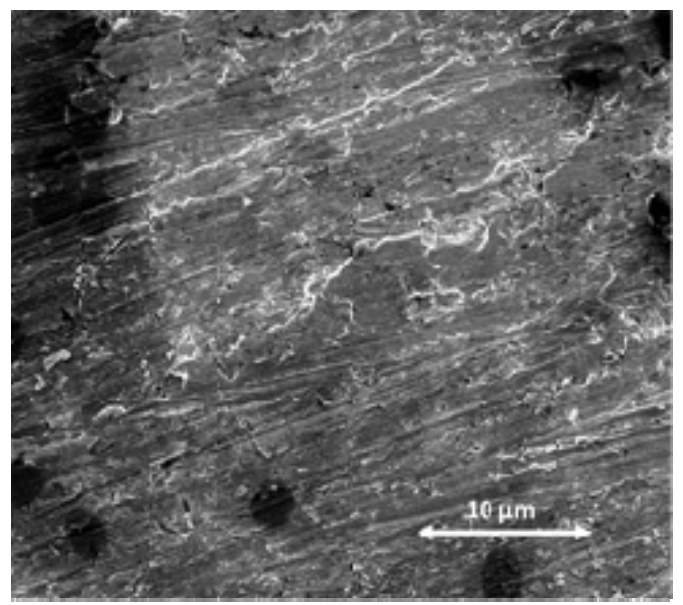

(b)

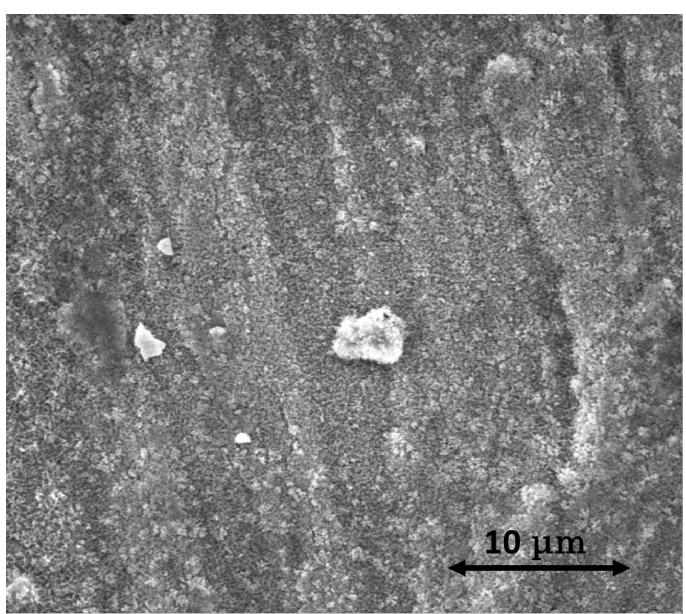

Fig.5 SEM image of the surface of bioactive titanium sample in situ $(\times 3000)$

(a) Control group ; no crystallization formation is observed.

(b) Ultrasound waving group ; The particles are formed on the Ti surface.

\section{$3 \cdot 1 \cdot 2$ 骨にインプラントしたチタン試料}

次に，大腿骨に埋入させたチタン試料を周囲の骨組織と一緒に取り出した試験片の断面の SEM 画像を図 6 に 示す.

(a)

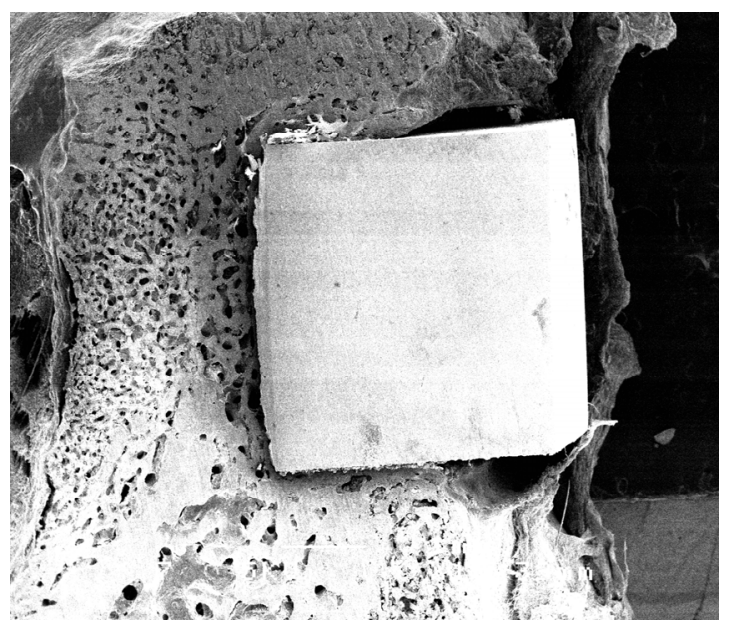

(b)

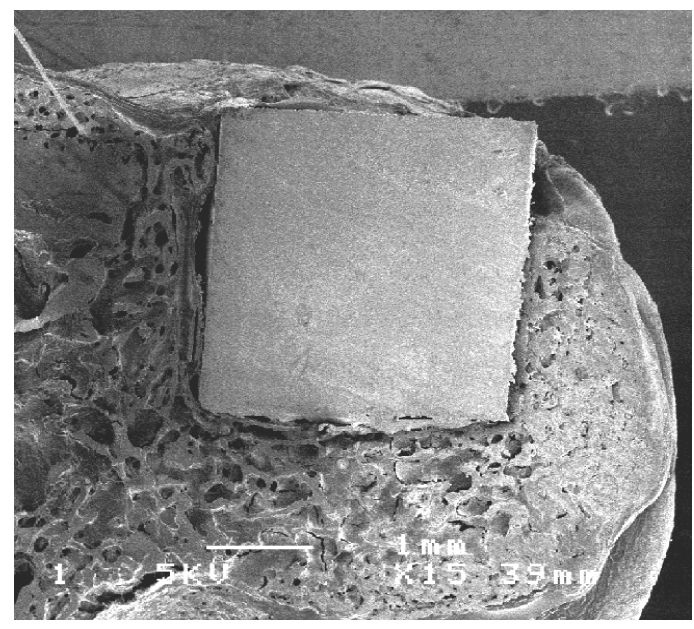

Fig.6 SEM image of bioactive titanium sample into femoral bone $(\times 50)$
(a) Control group
(b) Ultrasound waving group

はっきりとしたチタンと骨との結合界面層は確認できなかったが，全体的に超音波照射した試料の方が骨とチ タンとの間隙が少なく, 拡大画像でも，一部にチタンと骨とが密着している部位が多く存在していた（図 7). 後 述するように，引き抜いた後のチタン試料表面では，マクロ，ミクロ観察ともにチタンに骨組織が直接結合して 
いることが確認されているので，この部位（円形内）ではチタンと骨との直接結合領域が存在していると推察さ れる.

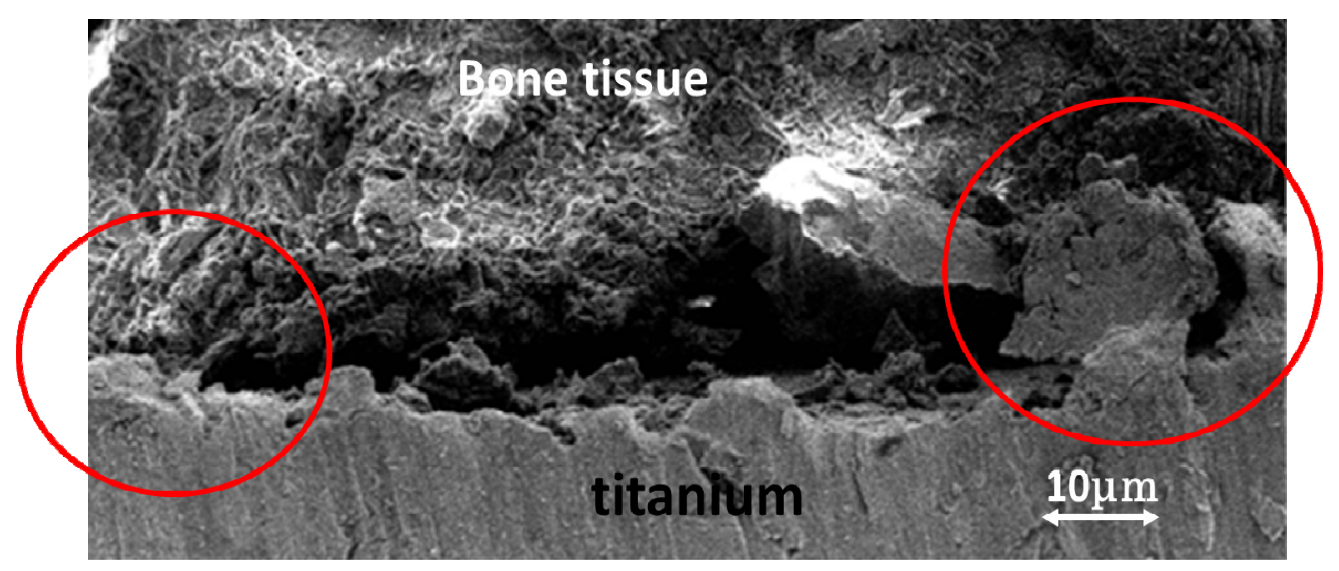

Fig.7 SEM image of the interface between the bioactive titanium sample and bone tissue $(\times 3000)$

\section{$3 \cdot 1 \cdot 3$ 骨から引い抜いたチタン試料}

骨から引き抜いた後の生体活性チタン表面のマクロ写真を図 8 に示す.超音波照射群，コントロール群いずれ の場合も，肉眼的に骨組織が付着しているのが確認されたが，付着部の量，面積ともに超音波照射群の試料の方 が多かった.

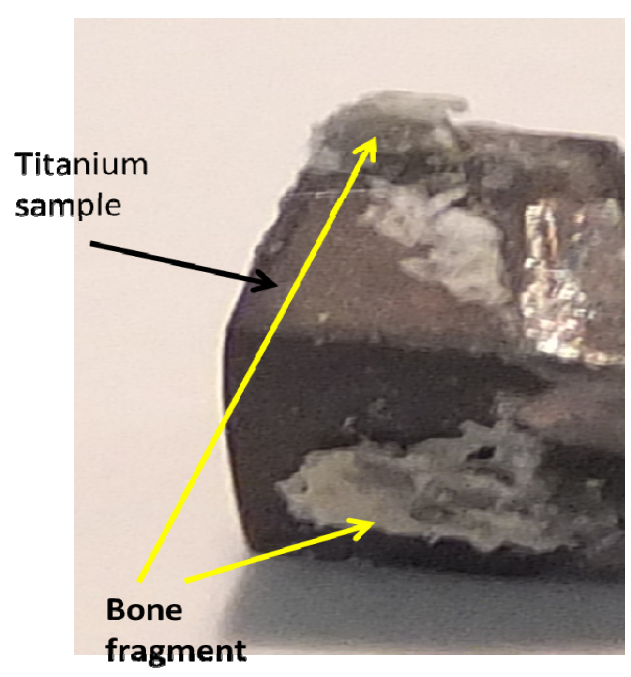

Fig.8 Macro appearance of the bioactive titanium sample surface after the pulled-out tests

肉眼的な骨の付着が確認されない領域でのチタン表面のミクロ観察の結果として, SEM 画像およびEDS の分 析結果を図 9 および図 10 に示す.

SEM で見ると，マクロでは平滑にみえる試料表面でも，超音波照射群，コントロール群ともに層状に沈着した 物質が観察された. 
(a)

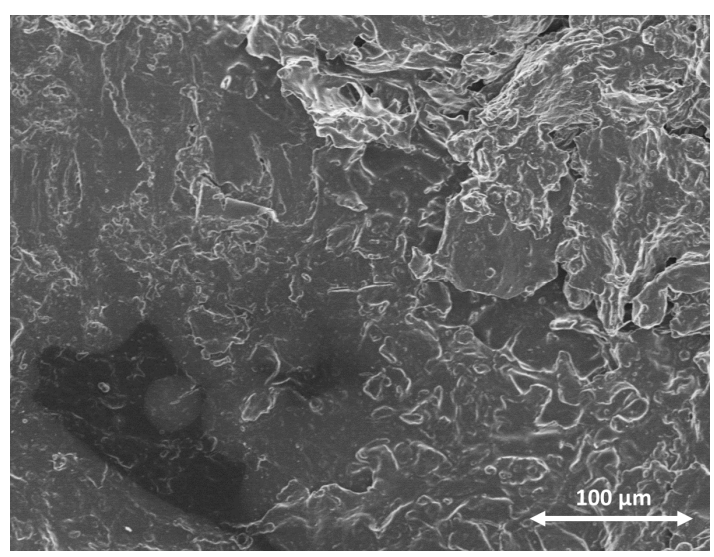

(b)

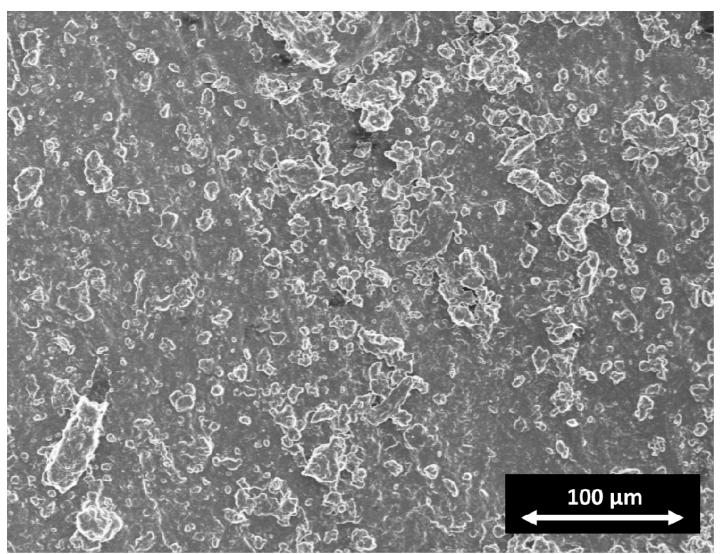

Fig.9 SEM image of bioactive titanium sample surface after the pulled-out tests $(\times 500)$

(a) Control group

(b) Ultrasound waving group

EDS によれば，チタン表面で観察された沈着物質は，P，O P Ca のピークが高く，リン酸カルシウム系化合物 $(\mathrm{Ca} / \mathrm{P}$ 系化合物 $)$ 寸なわち骨組織様アパタイトと考えられた. 以前に報告した in vitro の研究の場合とは異なり， このアパタイトが体液から析出したものか周囲の骨組織と結合・付着したものかは不明であるが, 全体としては, 超音波照射群での方が厚く量も多いことが確認された.

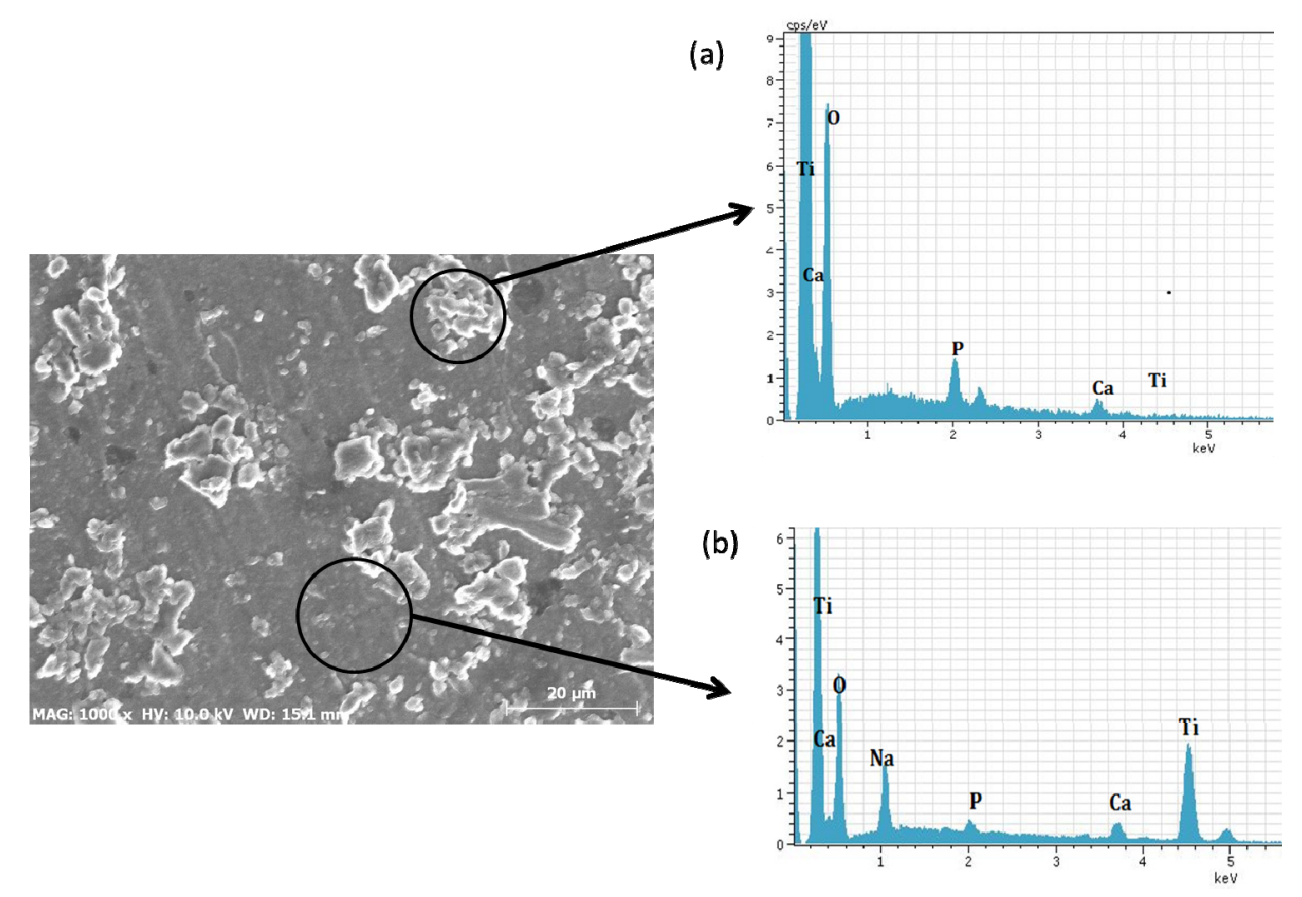

Fig.10 EDS analysis of Bioactive Ti surface implanted into femur for 2 weeks

(a) The precipitation indicates the composition of rich phosphate $(\mathrm{P})$ and calcium (Ca)

(b) The based surface shows high titanium (Ti) peak with $\mathrm{P}$ and $\mathrm{Ca}$ 


\section{$3 \cdot 2$ 組織標本観察}

図 11 にエオジン-ヘマトキシリン（H-E）染色による骨に入れたチタンインプラントと周囲の骨組織の組織写 真を示す.

(a)
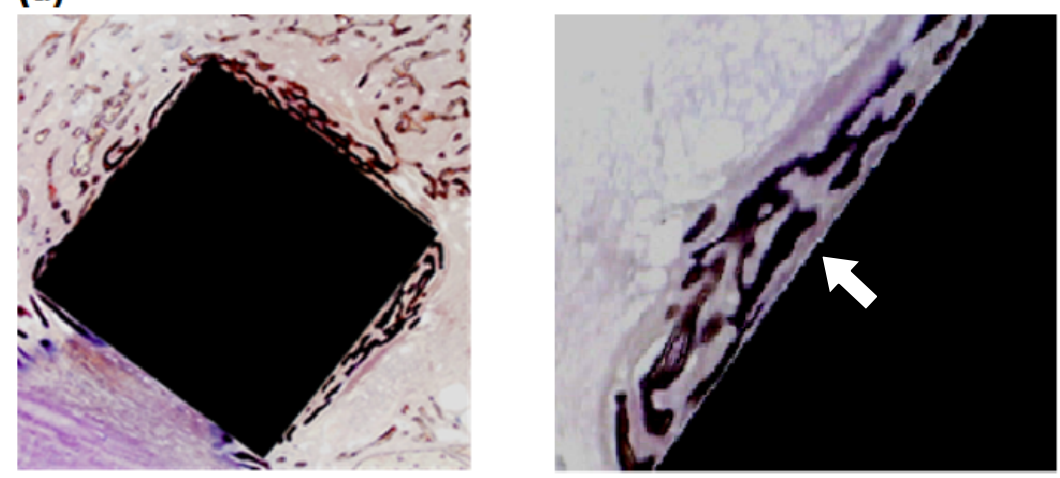

(b)
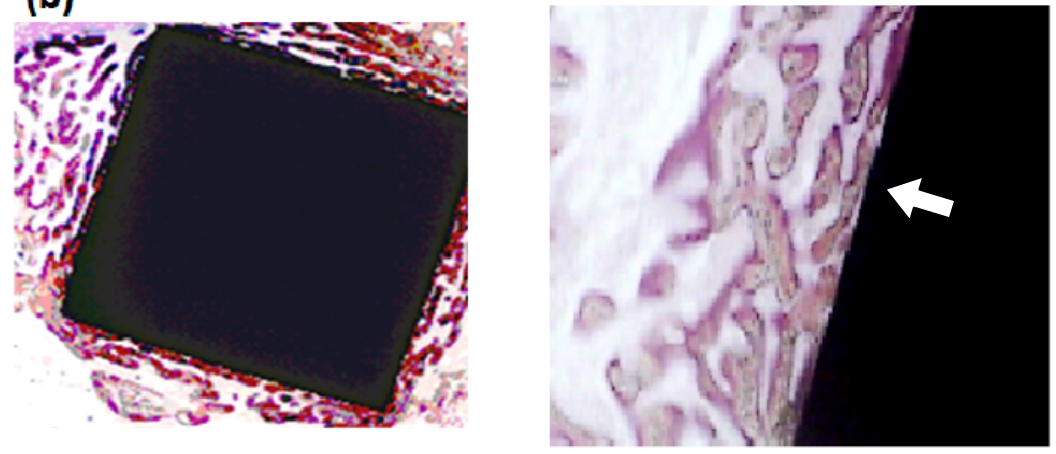

Fig.11 Histological appearance of the surface of bioactive titanium sample onto bone

(a) Control group (without ultrasound waving) (b) Ultrasound waving group

Two arrows show the interface between the titanium implant and bone tissue

術後 2 週間の状態で，超音波照射群，コントロール群 2 種類の試験片周囲にはいずれも周囲からの骨形成が認 められた．高倍率で見てみると，コントロールのチタン(a)ではほとんどの領域で骨梁と試料表面との間にまだ僅 かな空隙が存在しているのに対して, 超音波照射の試験片(b)では生体骨と直接結合している部位がいくつか観察 された ( $\rightarrow$ 部参照).

\section{$3 \cdot 3$ 機械試験}

引き抜き試験での超音波照射群，コントロール群それぞれの荷重 - 変位曲線の一例を図 12(a)に，計測した引き 抜き強度の結果を図 $12(\mathrm{~b})$ に示寸。

試験での荷重 - 変位曲線の形は, 超音波照射群，コントロール群ともに相違はなかったが，骨とチタンとの結 合強度は，超音波照射群で高い傾向を示し,サンプル数は少ないながらも有意差（p<0.05）を認めた. 
(a)

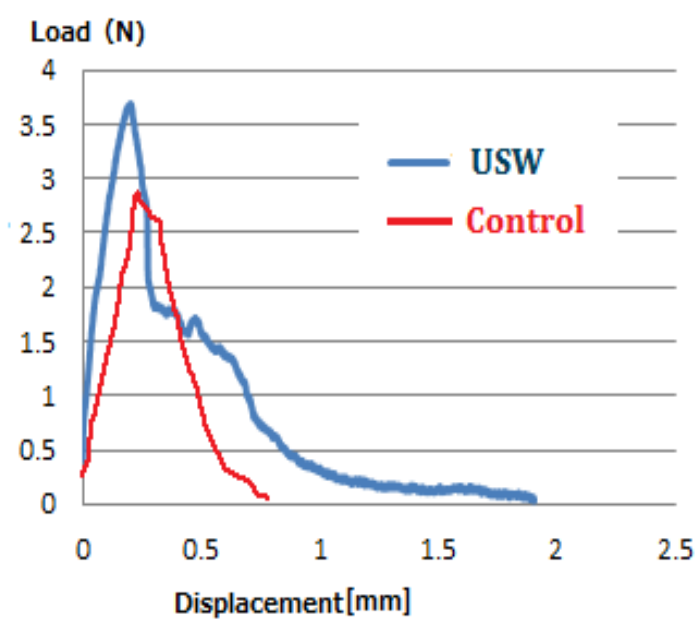

(b)

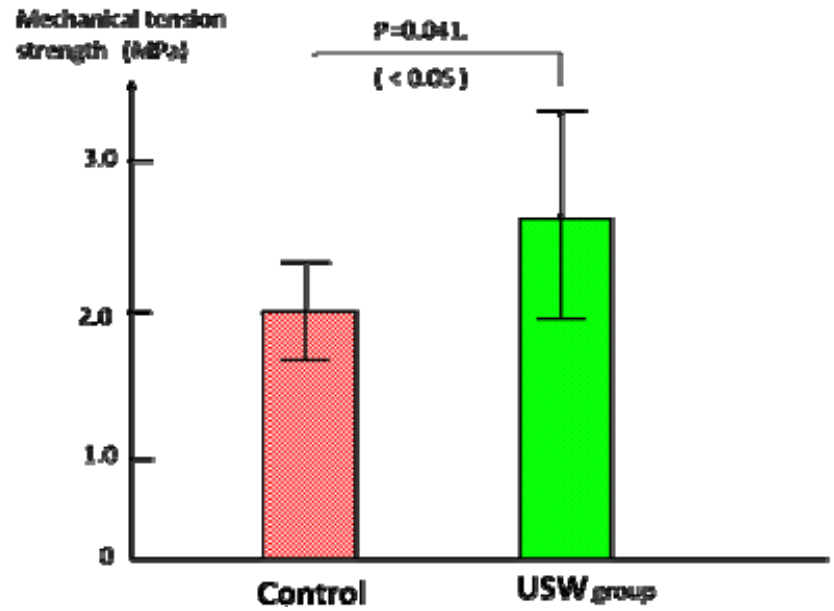

Fig.12 The results of pull-out tests

(a) The load-displacement relation curves

(b) Bone-titanium bonding strength

\section{4. 考察}

小久保らは，骨伝導性をもつバイオマテリアルの骨形成メカニズムとして，まずインプラントした周囲の体液 から材料表面への $\mathrm{PO}_{4}{ }^{2-}, \mathrm{Ca}^{2+}$ 等の物理的な沈着と骨と同様のアパタイト様物質の結晶析出過程が必要であり, この析出層が周囲の骨組織と結合していくと説明している ${ }^{(8,10)}$. この表面層でのアパタイトの析出過程では生物 学的要因のない全くの物理化学変化であり，この結晶析出過程をうまく促進させることができれば，結果として チタンと骨との結合期間も短縮させることが可能と考えられる. そして，今回の in vivo の実験でも，擬似体液中 に比べて全体に析出量が少ないものの，生体内でも，超音波による生体活性チタン表面での骨様アパタイトの析 出促進効果が確認された. In vitro の場合よりも析出量が少ない原因としては，実際の生体内でチタン表面に接触 する体液の量, 成分比や $\mathrm{pH}$ が理想的な条件ではないこと, さらに筋層や骨組織を介するため超音波照射のエネ ルギーが in vitro に比して十分に伝播しにくいこと等が考えられる.

これらの析出に関する超音波の効果メカニズムとしては, 序論でも述べたように, 生体内でも超音波によ る micro-waving や発熱によって, 体液中の $\mathrm{PO}_{4}$ や $\mathrm{Ca}$ イオンの濃度のゆらぎが生じて生体活性チタン表面で の不均一核生成が促進され, その後のアパタイト結晶の成長過程では, 機械的振動によってミクロな結晶破 壊が引き起こされて, 逆に成長スピードの早いエピタキシャルな面が多く形成されたのではないかと推察し ている．ただ超音波照射によって結晶化が促進されたことを報告した他の研究でも，この詳細なメカニズム については言及しておらず(5-7)，今後の解明が必要である.

また，動物実験では，単に生体活性チタン表面での超音波のアパタイト様物質の析出を促進と言う結晶学的作 用のみではなく，既に臨床でもエビデンスを得て広く応用されているように骨折の治瘉過程の生物学的促進，す なわち骨芽細胞への刺激による骨新生の超音波照射の効果 ${ }^{(11,12)}$ も相乗的に作用して, チタン周囲の骨組織の新生 を同時に促進することで，インプラントと骨との間隙もより早く埋まり結合できたと考えられる.

今回の実験では，生体活性チタンと骨との結合能力に関しての解析が，チタン表面での局所的なアパタイトの 析出状態の観察を通して議論されるために, 本来の超音波照射の生体活性促進を客観的に評価しづらい点がある. しかし，引き抜き試験で超音波照射郡が高い強度を示したことから，実際の臨床応用について見てみると，この 研究結果は, この骨との初期固定を促進するための手段として, 超音波照射の有效性, 可能性を示すもので 
ある. 現在生体活性チタンは人工股関節のステム材として使用されており，今後は人工歯根などのインプラント にも応用が検討されている. しかしこの材料の臨床上の課題として，まだハイドロキシアパタイトと比較すると 骨との直接結合にかかる時間が長く, リハビリテーションや術後機能の改善などの点から，より早期に強固に生 体骨と結合することが要求されている(13 15). 本研究での超音波照射効果は, この生体活性チタンの欠点克服に も寄与すると考えられるが，このチタンの骨との結合メカニズムは，他のハイドロキシアパタイト等の

Bio-active セラミックスでも同様であることから，超音波のインプラントと骨との臨床的な初期固定を促進す る効果は，他の生体活性を持つインプラントでも応用できると考えられる.

今後の臨床一の応用のためには, 超音波照射の生体内での安全性の確認とともに, 超音波の周波数や強度, 照 射回数など,アパタイトを含む $\mathrm{Ca} / \mathrm{P}$ 系化合物の結晶成長に大きく影響する因子についての最適条件を見出すこと とが重要な課題と考えられる.

\section{5. 結 語}

優れた生体適合性を持つチタンが, 今後さらに人工関節やデンタルインプラントとして発展するためには, チタン表面と生体骨とが直接早く結合する生体活性機能の向上が期待される. この研究では, さらに早期に インプラントの初期固定に対する超音波照射の有効性を調べた結果，以下の結果が得られた。

(1) ウサギの皮下内でのチタン表面でも, 超音波照射をうけた方でより多くの骨様アパタイト, $\mathrm{Ca} / \mathrm{P}$ 系化合 物の析出が観察された.

(2) 骨内に埋入したチタンでも，SEM や組織標本観察から，超音波照射群で，チタン試料と周囲の骨組織と の間隙が縮小して，結合部位の増幅が観察された．また，機械試験でも超音波照射を行ったグループで骨と のチタンとの結合強度が高かったことから，骨結合が促進されると考えられた．

今回の研究結果から, 今後 Bio-active なインプラントと骨との臨床的な初期固定を促進するための手段とし て, 超音波照射の有効性が示唆された.これらアパタイトの析出に関する超音波効果のメカニズムとしては, micro-waving や cavitation による $\mathrm{PO}_{4}$ や Ca イオンの濃度のゆらぎやエピタキシャルな結晶面の形成など結晶 学的な要因が推察されるが, その詳細はまだ不明であり, 最適条件の検索と共に今後の検討課題と考えられ る.

\section{文献}

(1) Ohnishi E, Fujibayashi S, Takemoto M, Neo M, Maruyama T, Kokubo T, Nakamura T. " Enhancement of bone-bonding ability of bioactive titanium by prostagrandin E2 receptor selective agonist". Biomaterials Vol.29 (2008), pp.877-883.

(2) Kokubo T, Takamada H, "How useful is SBF in predicting in vivo bone bioactivity?" Biomaterials Vol. 27 (2006), pp.2907-15.

(3) 小林 正典, 立松 尚紘, 野田 恵介 “擬似体液中での生体活性純チタンのハイドロキシアパタイト析出に おける低出力超音波パルス照射の影響について”日本機械学会論文集 A 編，Vol.75, No.757 (2009), pp.89-93.

(4) Kobayashi M, Tatematsu T, Noda K. "The effect of the low-intensity pulsed ultrasound waving stimulation on Hydroxyapatite formation on Bio-active pure titanium in Simulated Body Fluid." Journal of Environment and Engineering. Vol.6, No.3 (2011), pp.693-699.

（5）田中敦, 沢田康次, “樹枝状結晶成長における超音波の影響” 物性研究 Vol.52, No.4 (1989), pp.430-434.

(6) Ichitsubo T, Matsubara E. "Crystallization accelerated by ultrasound in Pd-based metallic glasses." Journal of Alloys and Compounds, Vol.434-5 (2006), pp.194-5.

(7) Ichitsubo T, Matsubara E "Ultrasound-induced crystallization around the glass transition temperature for Pd40Ni40P20 metallic glass.” Acta Materialia, Vol.52, No.2 (2004), pp.423-9. 
(8) Kokubo T, Yamaguchi S. “ Novel Bioactive Titanate Layers Formed on Ti Metal and Its Alloy by Chemical Treatments." Materials Vol. 3 (2010), pp.48-63.

(9) Nishiguchi S, Fujibayashi S, Kim HM, Kokubo T, Nakamura T. “Biology of alkali- and heat-treated titanium implants.” Journal of Biomedical Material Research A Vol.67(2003), pp.26-35.

(10) Kim HM, Kokubo T . " "Surface potential change in bioactive titanium metal during the process of apatite formation in simulated body fluid.” Journal of Biomedical Material Research A. Vol.67 (2003), pp.1305-9.

(11) 水野耕作，角田雅也，松井允三，藤田正和，滝川悟史，国分毅，“超音波骨折治療の現況” 整形・災害外科 Vol.43 (2000), pp.213-223.

(12) O’brien WD. “Ultrasound-biophysics mechanisms.” Progress in biophysics and molecular biology, Vol.93 (2007), pp.280-94.

(13) 黒田健介，興戸正純，“金属系バイオマテリアルの研究開発・最前線一骨組織との親和性を目指した金属表面処 理” 金属 Vol.277, No.2(2007), pp.141-7.

(14) 林和生 “人工関節とハイドロキシアパタイト”バイオマテリアル Vol.20, No.5 (2002), pp.322-328.

(15) 中村孝志編 “生体材料からみた人工関節の現況と展望一整形外科・増刊号 整形外科におけるバイオマテリア ルの現況と展望”南江堂 Vol.48, No.8 (1997), pp.978-982. 